\title{
Oral pharmacological treatments for parasitic diseases of rainbow trout Oncorhynchus mykiss. III: Ichthyobodo necator
}

\author{
J. L. Tojo*, M. T. Santamarina \\ Department of Microbiology and Parasitology, Laboratory of Parasitology, Faculty of Pharmacy, \\ Universidad de Santiago de Compostela, E-15706 Santiago de Compostela, Spain
}

\begin{abstract}
A total of 32 drugs were evaluated as regards their efficacy for oral treatment of Ichthyobodo necator infestation of rainbow trout. In preliminary trials, all drugs were supplied to infected fish at $40 \mathrm{~g}$ per $\mathrm{kg}$ of feed for $10 \mathrm{~d}$. The majority of the drugs tested (1,3-di-6-quinolylurea, aminosidine, amprolium, benznidazole, bithionol, chloroquine, diethylcarbamazine, dimetridazole, diminazene aceturate, febantel, flubendazole, ketoconazole, levamisole, mebendazole, netobimin, niclosamide, niridazole, nitroscanate, nitroxynil, oxibendazole, parbendazole, piperazine, praziquantel, ronidazole sulphaquinoxaline, tetramisole, thiophanate, toltrazuril and trichlorfon) were ineffective. Metronidazole and secnidazole were $100 \%$ effective (unlike the other nitroimidazoles tested, namely dimetridazole, benznidazole and ronidazole). The non-carbamate benzimidazole triclabendazole was likewise $100 \%$ effective.
\end{abstract}

KEY WORDS: Ichthyobodosis Rainbow trout $\cdot$ Treatment $\cdot$ Drugs

\section{INTRODUCTION}

One of the chief causes of mortality among intensively farmed fish is infestation with ectoparasites such as the flagellate Ichthyobodo necator. Ichthyobodosis is probably the most frequent external flagellate parasitosis among farmed fish, notably in young salmonids including rainbow trout. Heavily infected fish suffer high mortalities over a very short period due to rapid multiplication of the parasite and associated damage to the external epithelium. The most conspicuous early symptoms are excessive secretion of mucus and greyish white slime on the skin, while longer-term infestation may lead to extensive epidermal erosion and ulcer formation (Ghittino 1985, Stoskopf 1993).

In recent years, there has been little progress in the pharmacological treatment of ichthyobodosis, and only a small number of drugs have been shown to have anti-Ichthyobodo activity. In previous studies, we have

\footnotetext{
•E-mail: mpmatesa@usc.es
}

screened a series of drugs for anti-Ichthyobodo efficacy in bath treatment. Of the 40 drugs tested, the only one that proved $100 \%$ effective was bithionol at $25 \mathrm{mg}$ $\mathrm{l}^{-1}$, administered for $3 \mathrm{~h}$ daily on 2 consecutive days (Tojo 1993, Tojo et al. 1994a, b, c).

There have been a number of reports of the efficacy of oral pharmacological treatments against ectoparasitoses. For example, malachite green in feed is highly effective for the treatment of the cutaneous ectoparasite Ichthyophthirius multifiliis in ornamental fish (Schmahl et al. 1992), and is easily administered in this form. Orally administered diflubenzuron has proved effective against infections of Salmo salar by the copepod Lepeophtherius salmonis ('salmon lice') (Wallace et al. 1997). Ivermectin is likewise widely used as an anti-lice treatment in Atlantic salmon farms, and its derivatives also show such activity (Kerry \& Smith 1997).

Here, we report a screening study of possible oral pharmacological treatments of ichthyobodosis in rainbow trout. A total of 32 drugs were tested at high dosages ( $40 \mathrm{~g}$ per $\mathrm{kg}$ of feed, for $10 \mathrm{~d}$ ). Oral treatments 
have a number of advantages, including ease of administration and the fact that there is no need to handle the fish.

\section{MATERIALS AND METHODS}

Fish. Rainbow trout Oncorhynchus mykiss Walbaum (weighing $16 \mathrm{~g}$ at the start of the experiments) were obtained from a local fish farm (Piscifactorías Coruñesas S.A., Carballo, A Coruña, Spain) and acclimatized for at least $36 \mathrm{~h}$ before assay in a $350 \mathrm{l}$ tank with aeration and continuous flow of water $\left(15 \pm 3^{\circ} \mathrm{C}, \mathrm{pH} 6.5 \pm\right.$ $0.5)$ from a nearby spring. The natural light-dark cycle was simulated (14-16 h light:8-10 h dark). Fish were fed daily with a commercidi feed.

Infestation. At least $50 \%$ of the fish used in each assay showed high-intensity infestation by Ichthyobodo necator (Henneguy 1883), in some cases as a result of natural infestations contracted on the fish farm, in other cases following experimental infestation. Parasite-free fish were experimentally infested by holding them for 15 to $20 \mathrm{~d}$ in a $350 \mathrm{l}$ tank that also contained fish showing high-intensity infestation (40 uninfected fish to 20 infected fish). Twenty fish were then sampled at random for determination of infestation intensity (see below). Since infestation intensity was in all cases high in less than 10 of the 20 fish, the experimental infestation period was extended by $7 \mathrm{~d}$, after which time infestation intensity was determined again. This proved sufficient to achieve highintensity infestation in at least $50 \%$ of fish.

Determination of infestation intensity. Fish were anaesthetized by bathing in MS222 (Sandoz; $0.05 \mathrm{~g} \mathrm{l}^{-1}$ ) until respiration became weak. A mucus sample was then taken by gently scraping the body surface. The sample was mixed with 3 drops of water on a slide, coverslipped and examined with a light microscope $(400 \times)$. Infestation intensity was recorded on a 5-point scale, after examination of a sample area of $24 \times 32 \mathrm{~mm}$, as follows: 'zero' (-), Ichthyobodo necator not detected in the sample; 'minimal' $(+/-)$, only 1 individual of $I$. necator detected in the sample; 'low' $(+)$, more than 1 individual of $I$. necator detected in the sample, the average number per microscope field being less than 10; 'moderate' $(++)$, average number of individuals per microscope field 10 to 50; 'high' $(+++)$, average number of individuals per microscope field more than 50 .
Drugs and assay design. The drugs tested in the study are listed in Table 1 . Each drug was assayed in 20 infected fish maintained in an $80 \mathrm{l}$ tank with continous flow (5 $1 \mathrm{~min}^{-1}$ ). A simultaneous control assay (also of 20 fish; identical treatment, but without drug) was performed for each drug. Tank conditions (water source, flow, aeration, $\mathrm{pH}$, temperature, light/dark cycle) were identical to those during the acclimatization period. The treated fish received feed containing $40 \mathrm{~g}$ per $\mathrm{kg}$ of drug for $10 \mathrm{~d}$. In all cases feed was supplied at $2 \%$ of total body weight per day. Throughout the assay period the fish were monitored regularly to ensure that they were eating the food, and to check for signs of toxicity. Twenty-four hours after the end of the assay (i.e. $11 \mathrm{~d}$ after the start), intensity of infestation of all fish was determined as above. Drugs found to be effective at the screening dosage were subsequently tested at lower dosages and/or duration (see 'Results').

\section{RESULTS}

Of the 32 drugs tested, 29 were not effective (i.e. did not completely eliminate infection); the results for these

Table 1. Drugs used in the present study, showing manufacturer, brand name and form of presentation. p.p.: pure product

\begin{tabular}{|c|c|c|c|}
\hline Drug & Brand name & Form & Manufacturer \\
\hline 1,3-di-6-quinolylurea & p.p. & Powder & Bayer \\
\hline Aminosidine & Gabbrocol & Injectable & Vetern S.P.A. \\
\hline Amprolium & Prolsal & Powder & Iteve \\
\hline Benznidazole & p.p. & Powder & Roche \\
\hline Bithionol & p.p. & Powder & Syva \\
\hline Chloroquine & p.p. & Powder & Cidan \\
\hline Diethylcarbamazine & p.p. & Powder & Cidan \\
\hline Dimetridazole & p.p. & Powder & Msd-Agvet \\
\hline Diminacene & Berenil & Granulate & Hoechst \\
\hline Febantel & p.p. & Powder & Bayer \\
\hline Flubendazole & p.p. & Powder & Esteve \\
\hline Ketoconazole & p.p. & Powder & Janssen \\
\hline Levamisole & p.p. & Powder & Ovejero \\
\hline Mebendazole & p.p. & Powder & Esteve \\
\hline Metronidazole & Flagyl & Powder & Rhone Mérieux \\
\hline Netobimin & p.p. & Powder & Ovejero \\
\hline Niclosamide & Fugotenil & Pills & Uriach \\
\hline Niridazole & Ambilhar & Pills & Janssen \\
\hline Nitroscanate & Lopatol 500 & Pills & Ciba-Geigy \\
\hline Nitroxynil & p.p. & Powder & Ovejero \\
\hline Oxibendazole & p.p. & Powder & Syva \\
\hline Parbendazole & p.p. & Powder & Smith Kline \\
\hline Piperazine & Pipersol & Granulate & Sobrino \\
\hline Praziquantel & Droncit & Pills & Bayer \\
\hline Ronidazole & p.p. & Powder & Sobrino \\
\hline Secnidazole & p.p. & Powder & Rhone Mérieux \\
\hline Sulphaquinoxaline & p.p. & Powder & Smith Kline \\
\hline Tetramisole & p.p. & Powder & Ovejero \\
\hline Thiophanate & p.p. & Powder & Uriach \\
\hline Toltrazuril & p.p. & Powder & Bayer \\
\hline Trichlorfon & Neguvón & Powder & Bayer \\
\hline Triclabendazole & p.p. & Powder & Ciba-Geigy \\
\hline
\end{tabular}


Table 2. Results of the assays that proved ineffective. For each drug (in all cases administered at $40 \mathrm{~g}$ per $\mathrm{kg}$ of feed for $10 \mathrm{~d}$ ), infection intensity $24 \mathrm{~h}$ post-treatment (as evaluated by examination of body scrapings; see text) is shown for each of the 20 fish included in the assay for that drug. Infection intensity: +++ , high; ++ , moderate,$+ l^{\prime} w_{;}+/-$, minimal $_{i}-$, zero (i.e. no Ichthyobodo necator detected in body scrapings); nd: not determined

\begin{tabular}{|c|c|c|c|c|c|c|c|c|c|c|c|c|c|c|c|c|c|c|c|c|}
\hline \multirow{2}{*}{$\begin{array}{l}\text { Drug ( } 40 \text { per } \mathrm{kg} \\
\text { feed for } 10 \mathrm{~d} \text { ) }\end{array}$} & \multirow[b]{2}{*}{1} & \multirow[b]{2}{*}{2} & \multirow[b]{2}{*}{3} & \multirow[b]{2}{*}{4} & \multirow[b]{2}{*}{5} & \multirow[b]{2}{*}{6} & \multirow[b]{2}{*}{7} & \multicolumn{3}{|c|}{ Trout number } & \multirow[b]{2}{*}{11} & \multirow[b]{2}{*}{12} & \multirow[b]{2}{*}{13} & \multirow[b]{2}{*}{14} & \multirow[b]{2}{*}{15} & \multirow[b]{2}{*}{16} & \multirow[b]{2}{*}{17} & \multirow[b]{2}{*}{18} & \multirow[b]{2}{*}{19} & \multirow[b]{2}{*}{20} \\
\hline & & & & & & & & 8 & 9 & 10 & & & & & & & & & & \\
\hline 1,3-di-6-quinolylurea & +++ & $++t$ & +++ & +++ & +++ & ++ & + & + & -- & - & - & - & - & - & - & - & - & - & - & - \\
\hline Aminosidine & $t+t$ & +++ & ++ & $+/-$ & - & - & - & - & - & - & - & - & - & -- & - & - & - & - & - & - \\
\hline Amprolium & +++ & +++ & +++ & +++ & $+t+$ & ++ & t+ & + & + & + & + & - & - & - & - & - & - & - & - & - \\
\hline Benznidazole & +++ & ++ & ++ & - & - & - & - & - & - & - & - & - & - & - & - & - & - & - & - & - \\
\hline Bithionol & +++ & +++ & +++ & ++ & ++ & ++ & ++ & ++ & ++ & + & - & - & - & - & - & - & - & - & - & - \\
\hline Chloroquine & +++ & +++ & +++ & +++ & +++ & +++ & +++ & +++ & +++ & +++ & +++ & +++ & +++ & +++ & +++ & ++ & ++ & + & + & + \\
\hline Diethylcarbamazine & +++ & ++ & + & $+/-$ & $+1-$ & $+/-$ & $+/-$ & - & - & - & - & - & - & - & - & - & - & - & - & - \\
\hline Dimetridazole & +++ & +++ & +++ & +++ & +++ & ++ & ++ & ++ & ++ & ++ & + & + & + & - & - & - & - & - & - & - \\
\hline Diminazene & +++ & +++ & +++ & +++ & +++ & +++ & +++ & +++ & ++ & ++ & ++ & ++ & + & + & + & - & - & - & - & - \\
\hline Febantel & +++ & +++ & +++ & +++ & +++ & +++ & +++ & t+ & ++ & + & + & - & - & - & - & - & - & - & - & - \\
\hline Flubendazole & +++ & ++ & ++ & + & + & $+1-$ & - & - & - & - & - & - & - & - & - & - & - & - & - & - \\
\hline Ketoconazole & +++ & +++ & +++ & +++ & +++ & +++ & ++ & ++ & ++ & + & - & - & - & - & - & - & - & - & - & - \\
\hline Levamisole & +++ & +++ & +++ & ++ & ++ & + & + & + & + & $+1-$ & $+/-$ & $+1-$ & - & - & - & - & - & - & - & - \\
\hline Mebendazole & +++ & +++ & +++ & +++ & +++ & +++ & ++ & t+ & ++ & ++ & + & + & $+1-$ & $+1-$ & - & - & - & - & - & nd \\
\hline Netobimin & +++ & +++ & t+t & ++ & t+ & ++ & + & + & + & + & + & + & + & $+1-$ & $+1-$ & - & - & -- & - & - \\
\hline Niclos & +++ & +++ & +++ & +++ & +++ & t+ & ++ & t+ & ++ & ++ & ++ & + & + & + & + & - & - & - & - & - \\
\hline Niridazole & +++ & +++ & +++ & +++ & +++ & $++t$ & +++ & +++ & +++ & +++ & +++ & +++ & +++ & +++ & +++ & +++ & ++ & - & - & nd \\
\hline Nitroscanate & + & + & + & $+/-$ & - & - & - & - & - & - & - & - & - & - & - & - & - & - & - & - \\
\hline Nitroxynil & +++ & +++ & +++ & +++ & +++ & ++ & ++ & ++ & + & + & + & - & - & - & - & - & - & - & nd & nd \\
\hline Oxibendazole & +++ & +++ & +++ & +++ & ++ & t+ & + & + & + & - & - & - & - & - & - & - & - & - & - & - \\
\hline Parbendazole & +++ & +++ & $+/-$ & $+/-$ & - & - & - & - & - & - & - & - & - & - & - & - & - & - & - & - \\
\hline Piperazine & +++ & +++ & +++ & +++ & +++ & +++ & +++ & +++ & $++t$ & +++ & +++ & +++ & +++ & +++ & +++ & +++ & +++ & $+t+$ & nd & nd \\
\hline Praziquentel & +++ & $+t+$ & +++ & +++ & +++ & +++ & +++ & t+ & ++ & ++ & ++ & + & + & + & + & - & - & - & - & - \\
\hline Ronidazole & + & $+1-$ & $+1-$ & $+1-$ & $+1-$ & - & - & - & - & - & - & - & - & - & - & - & - & - & - & - \\
\hline Sulphaquinoxaline & +++ & +++ & +++ & +++ & +++ & +++ & +++ & +++ & ++ & ++ & ++ & ++ & + & - & - & - & - & - & - & - \\
\hline Tetramisole & ++ & ++ & + & + & + & + & + & + & $+1-$ & - & - & - & - & - & - & - & - & - & - & - \\
\hline Thiophanate & +++ & +++ & +++ & +++ & +++ & +++ & +++ & +++ & +++ & +++ & +++ & ++ & ++ & ++ & + & + & + & + & + & - \\
\hline Toltrazuril & $++t$ & +++ & +++ & +++ & +++ & +++ & +++ & +++ & ++ & ++ & ++ & + & + & - & - & - & - & - & - & - \\
\hline Trichlorfon & +++ & +++ & +++ & +++ & +++ & +++ & +++ & +++ & +++ & +++ & +++ & +++ & +++ & +++ & +++ & + & - & - & - & - \\
\hline
\end{tabular}

drugs are listed in Table 2 . The results for the 3 effective drugs (metronidazole, secnidazole and triclabendazole) are listed in Table 3 ; both eliminated infection in all 20 fish included in each assay. Metronidazole was effective only at the screening dosage ( $40 \mathrm{~g}$ per $\mathrm{kg}$ feed for $10 \mathrm{~d}$ ), while secnidazole was effective at $20 \mathrm{~g}$ per $\mathrm{kg}$ feed for $2 \mathrm{~d}$, and triclabendazole at $40 \mathrm{~g}$ per $\mathrm{kg}$ feed for $5 \mathrm{~d}$ (Table 3 ). None of the 3 effective drugs had evident toxic effects.

Table 3. Results of the assays for drugs that proved effective. For each drug and each dosage tested, infestation intensity $24 \mathrm{~h}$ after the end of the assay (as evaluated by examination of body scrapings; see text) is shown for each of the 20 fish included in each assay. Results of control assays are also shown. Infestation intensity: +++ , high $;++$, moderate + , low; $+/-$; minimal - , zero (i.e. no Ichthyobodo necator detected in body scrapings). The initial prevalence of infestation was at least $50 \%$ in all groups

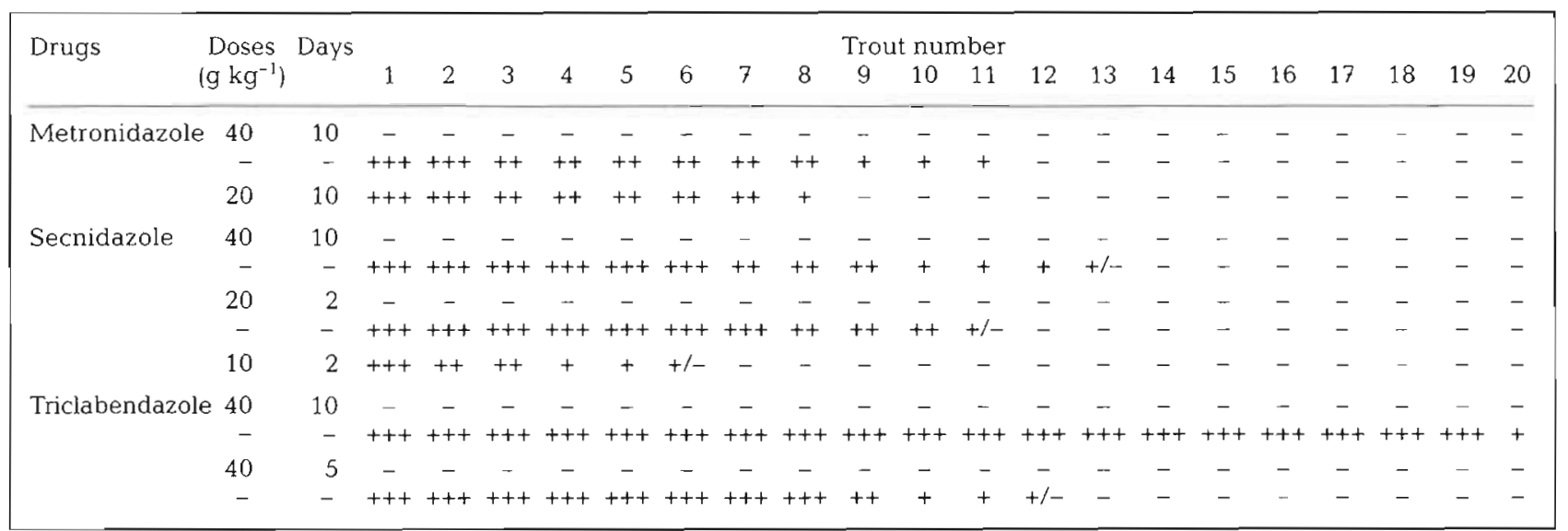




\section{DISCUSSION}

None of the 32 drugs tested showed evidence of toxicity to rainbow trout at the dosages used. Of the 32 drugs, 14 have been tested previously for efficacy against ichthyobodosis in bath treatment, while the remaining 18 have not been assayed previously against Ichthyobodo necator (though they have been assayed against other internal or external fish parasitoses). The 18 drugs not tested to date are diethylcarbamazine, dimetridazole, febantel, flubendazole, levamisole, mebendazole, netobimin, nitroscanate, nitroxynil, oxibendazole, parbendazole, piperazine, praziquantel, ronidazole, secnidazole, tetramisole, thiophanate and triclabendazole.

Of these 18 drugs, the oniy ones to show anti-Ichthyobodo activity in the present study were secnidazole and triclabendazole. Secnidazole was $100 \%$ effective at dosages as low as $20 \mathrm{~g}$ per $\mathrm{kg}$ of feed for $2 \mathrm{~d}$, and triclabendazole at dosages as low as $40 \mathrm{~g}$ per $\mathrm{kg}$ of feed for $5 \mathrm{~d}$. Both drugs have been tested previously against protozoan parasites of fish, and have been assayed by us in a study of possible oral pharmacological treatments of Hexamita salmonis infection of rainbow trout (Tojo \& Santamarina 1998). In this latter study, secnidazole was $100 \%$ effective at doses as low as $2 \mathrm{~g}$ per $\mathrm{kg}$ of feed for $2 d_{\text {i }}$ triclabendazole was very nearly $100 \%$ effective at the screening dosage $(40 \mathrm{~g}$ per $\mathrm{kg}$ of feed for $10 \mathrm{~d}$ ), a single parasite being detected in the intestine of one of the 20 fish included in the assay. The greater activity of secnidazole may be related to the fact that this drug has a longer half-life than other nitroimidazoles (Dupouy Camet 1994).

Triclabendazole is known to have anthelmintic activity, and is used as an anthelmintic in livestock; the results of the present study, indicating that it also shows antiprotozoal activity, require confirmation. Other drugs, such as albendazole, show both anthelmintic and antiprotozoal activity (Tojo \& Santamarina 1998).

The present results also indicate that metronidazole is $100 \%$ effective against Ichthyobodo necator, although only at the screening dosage $(40 \mathrm{~g}$ per $\mathrm{kg}$ of feed for $10 \mathrm{~d}$ ). In our previous study of effectiveness against Hexamita salmonis (Tojo \& Santamarina 1998), metronidazole was effective at doses as low as $5 \mathrm{~g}$ per $\mathrm{kg}$ of feed for $2 \mathrm{~d}$ (again lower activity than secnidazole). Another previous study found that bath treatment of Octopus bimaculoides with metronidazole (200 $\mathrm{mg} \mathrm{l}^{-1}$ for 4 d) was not sufficient to eliminate I. necator infection (Forsyte et al. 1991).

In our previous study of possible bath treatments (Tojo et al. 1994c), neither trichlorfon and niridazole (200 $\mathrm{mg} \mathrm{l}^{-1}$ for $3 \mathrm{~h}$ ) nor niclosamide $\left(3 \mathrm{mg} \mathrm{l}^{-1}\right.$ for $3 \mathrm{~h}$ ) were effective against Ichthyobodo necator. These drugs were likewise ineffective in the present study.
Neither in this study nor in previous studies have we observed signs of toxicity of any of these drugs.

We have previously screened amprolium, chloroquine, ketoconazole, sulphaquinoxaline and toltrazuril (in all cases at $200 \mathrm{mg} \mathrm{l}^{-1}$ ), together with 1,3-di-6quinolylurea and diminazene aceturate (in both cases at $100 \mathrm{mg} \mathrm{l}^{-1}$ ) and bithionol (at $35 \mathrm{mg} \mathrm{l}^{-1}$ ), for efficacy in bath treatment $(3 \mathrm{~h})$ against Ichthyobodo necator (Tojo et al. 1994b). The only drug which was effective was bithionol ( $25 \mathrm{mg} \mathrm{l}^{-1}$ for $3 \mathrm{~h}$ on 2 consecutive days). In the present study, however, neither bithionol nor any of these drugs was effective. Note also that none of these drugs showed toxic effects in the present study, despite our previous finding (Tojo et al. 1994b) that both bithionol at $35 \mathrm{mg} \mathrm{l}^{-1}$ and diminazene aceturate at $100 \mathrm{mg} \mathrm{l}^{-1}$ have toxic, and in some cases lethal, effects.

In conclusion, most of drugs tested in the present study are clearly of no value for oral-route treatment of ichthyobodosis in rainbow trout, given that the screening dosage was already very high. The only drugs which were effective were metronidazole, secnidazole and triclabendazole. In all 3 cases, however, the required dose was too high to be economically viable, except possibly in situations in which bath treatment is not possible.

\section{LITERATURE CITED}

Dupouy Camet $\mathrm{J}$ (1994) Single dose treatments in tropical infectious diarrhoea: the place of secnidazol. Drug Invest $8(1): 35-46$

Forsythe FW, Hanlon RT, Bullis RA, Noga EJ (1991) Octopus bimaculoides (Pickford \& Mcconnarghey, 1949) a marine invertebrate host for ectoparasitic protozoans. J Fish Dis $14: 431-442$

Ghittino P (1985) Tecnologia e patologia in acquacoltura. II Patologia. Tipografía Emilio Bono, Turin

Henneguy LF (1883) Sur un infusoire flagellé ectoparasite des poissons. C R Acad Sci 96:658-660

Kerry J, Smith P (1997) Evidence for an antibacterial action associated with Ivomec ${ }^{\mathrm{TM}}$. VIII. European Association of Fish Pathologists. International Conference on Diseases of Fish and Shellfish. Edinburgh, Scotland, 14-19 September, 1997

Schmahl G, Ruider S, Mehlhorn H, Schmidt H, Ritter G (1992) Treatment of fish parasites. 8. Effects of medicated food containing malachite green on Ichthyophthirius multifilis Fouquet. 1876 (Hymenostomatida, Ciliophora) in ornamental fish. Parasitol Res 78:183-192

Stoskopf MK (1993) Fish medicine. WB Saunders Company, Philadelphia, PA

Tojo JL (1993) Tratamiento farmacológico de ectoparásitosis en trucha (Oncorhynchus mykiss): Gyrodactylus sp., Ichthyobodo necator e Ichthyophthirius multifiliis. Doctoral thesis, University of Santiago de Compostela

Tojo JL, Leiro J, Estevez J, Ubeira FM, Paniagua E, Santamarina MT (1994a) Tratamiento farmacológico de Ichthyobodosis en trucha. Acta Parasitol Port 1(2):293

Tojo J, Santamarina MT (1998) Oral pharmacological treatments for parasitic diseases of rainbow trout Oncorhyn- 
chus mykiss. I: Hexamita salmonis. Dis Aquat Org 33(1): $51-56$

Tojo JL, Santamarina MT, Leiro J, Ubeira FM, Sanmartín ML (1994b) Pharmacological treatments against Ichthyobodo necator (Henneguy, 1883) in rainbow trout, Oncorhynchus mykiss (Walbaum). J Fish Dis 17:135-143

Tojo JL, Santamarina MT, Ubeira FM, Leiro J, Sanmartín ML (1994c) Attempts to control Ichthyobodo necator in rain-

Editorial responsibility: Wolfgang Körting,

Hannover, Germany bow trout (Oncorhynchus mykiss) by bath treatment. Bul Eur Assoc Fish Pathol 14(1):1-4

Wallace C, Melstveit L, Toneby M (1997) Preclinical dose response studies with diflubenzuron against salmon lice (Lepeophtherius salmonis) on Atlantic salmon (Salmo salar). VIII European Association of Fish Pathologists. International Conference on Diseases of Fish and Shellfish. Edinburgh, Scotland, 14-19 September, 1997

Submitted: March 10, 1998; Accepted: May 15, 1998

Proofs received from author(s): July 15, 1998 